\title{
Uma proposta de multiletramento com o gênero meme em aulas de leitura
}

\section{A multiliteracy proposal using the genre meme in reading classes}

\author{
Lilian Cristina Buzato Ritter ${ }^{1}$
}

DOI: $10.28998 / 2317-9945.2020 \mathrm{n} 64 \mathrm{p} 4-19$

\section{Resumo}

Este trabalho apresenta reflexões teórico-analiticas acerca de um processo de elaboração didática com práticas de leitura com o gênero meme, em um nono ano da rede pública de ensino do estado do Paraná. A configuração geral da proposta didática foi determinada a partir de quatro módulos temáticos relacionados com a falta de valores éticos, as intolerâncias sociais como bullying, racismo, machismo e homofobia. $O$ trabalho segue a linha teórico-metodológica dos estudos dialógicos bakbtinianos e ancora-se na concepção interacionista e dialógica da linguagem para o ensino e aprendiragem de Lingua Portuguesa, preocupando-se também com a inserção de práticas de multiletramentos com textos multissemióticos nas aulas de leitura. Podemos afirmar que os resultados demonstraram que houve a adoção mais de um estilo docente internamente persuasivo do que de um estilo autoritário (ROJO, 2008).

Palavras-chave: Memes. Multiletramento. Leitura

\begin{abstract}
This work presents theoretical-analytical reflections regarding a process of didactic elaboration with reading practices using the genre meme in a ninth grade class of a public school in Paraná. The general configuration of the didactic proposal was determined based on four theme books that deals with the lack of ethical values and social intolerances such as bullying, racism, male chawinism and homophobia. This work was developed following the theoretical-methodological framework of Bakbtinian dialogic studies and it is based on the interactionist and dialogic conception of language for the teaching and learning of Portuguese, and it is also concerned with the insertion of multiliteracy practices using multisemiotic texts in reading classes. We can say that the results show that there was an adoption of an internally persuasive teaching style rather than an authoritarian one (ROJO, 2008).
\end{abstract}

Keywords: Memes. Multiliteracy. Reading

Recebido em: 31/03/2018.

Aceito em: 24/08/2018.

\footnotetext{
1 Professora do Departamento de Língua Portuguesa da Universidade Estadual de Maringá, atuando no Profletras. Doutora em Estudos da Linguagem pela Universidade Estadual de Londrina.
} 


\section{Introdução}

O presente trabalho insere-se em uma pesquisa desenvolvida no Programa de Mestrado Profissional em Rede (Profletras/UEM/Capes) que buscou desenvolver uma proposta de prática de leitura e análise linguística com o gênero meme em um nono ano da educação básica da rede estadual de ensino paranaense, articulando-se com o Projeto de Pesquisa "Formação do professor de Língua Portuguesa e práticas de linguagem em sala de aula: múltiplos olhares" (UEM). A proposta se concretizou em um "Protótipo Didático" que, de acordo com Rojo e Moura (2012, p. 8), é definido como "estruturas flexíveis e vazadas que permitem modificações por parte daqueles que queiram utilizá-las em outros contextos que não o das propostas iniciais".

A ancoragem teórica está na linha dos estudos dialógicos do Círculo de Bakhtin (BAHKTIN, 2003; BAKHTIN; VOLOCHINOV, 1988) e na concepção interacionista e dialógica da linguagem para o ensino e aprendizagem de Língua Portuguesa, preocupandose também com a inserção de práticas de multiletramentos com textos multissemióticos nas aulas de leitura (ROJO; BARBOSA, 2015).

Optou-se pela elaboração do protótipo didático com o gênero discursivo meme, pois ele está presente em todas as redes sociais, é de fácil divulgação, e, geralmente, tem interpretação de humor ou sátira, algo que sempre agrada os alunos na idade da turma selecionada. As atividades foram desenvolvidas pela professora-pesquisadora (doravante, $\mathrm{P}$ ) em seu horário normal de aula, durante o ano letivo de 2017, durante os meses de agosto e setembro, totalizando $20 \mathrm{~h} / \mathrm{a}$. Para a produção deste artigo, houve um recorte do protótipo didático, focalizando o momento de planejamento do módulo didático que tratou acerca do tema "racismo".

$\mathrm{O}$ artigo em tela apresenta-se estruturado em duas principais partes. $\mathrm{O}$ primeiro trata dos aspectos teóricos referentes aos conceitos bakhtinianos de enunciado concreto, responsividade e o gênero discursivo meme. O segundo apresenta reflexões a respeito das relações pedagógicas adotadas por $\mathrm{P}$, no momento do planejamento do módulo em questão.

\section{Enunciado concreto, responsividade e o gênero discursivo meme}

Antes de iniciarmos propriamente as discussões desta seção, faz-se pertinente asseverarmos que o uso dos termos "enunciado" e "enunciação", dependendo da perspectiva teórica, pode causar controvérsias e polêmicas. Destarte, Barbosa (2001) esclarece que o conceito de enunciado concreto, no pensamento bakhtiniano, recobre os termos enunciado e enunciação, dado que o enunciado é, ao mesmo tempo, produto - no sentido de ser um acontecimento único - e processo - pela sua condição permanente de elo da cadeia de comunicação verbal. Feitas essas explicações, passamos a tecer discussões teóricas em torno dos conceitos enunciado concreto e responsividade.

As ideias fundadoras do Círculo de Bakhtin, especialmente as presentes em Marxismo e filosofia da linguagem, ao criticarem as duas principais teorias linguísticas em curso no seu tempo, a do objetivismo abstrato e a do subjetivismo individualista, construíram a base de sua epistemologia filosófica da linguagem com a noção de enunciado concreto. 
Nesse âmbito, invertem valores da linguagem e da língua cristalizados até aquele momento, argumentando que a língua é um signo ideológico:

A verdadeira substância da língua não é constituída por um sistema abstrato de formas linguísticas, nem pela enunciação monológica isolada, nem pelo ato psicofisiológico de sua produção, mas pelo fenômeno social da interação verbal, realizada através da enunciação ou das enunciações. A interação verbal constitui assim a realidade fundamental da língua (BAKHTIN; VOLOCHINOV, 1988, p. 123).

Dessa forma, observamos a importância da noção de enunciado concreto na concepção de linguagem que rege o pensamento bakhtiniano, porque a linguagem é concebida de um ponto de vista histórico, cultural e social que inclui, para efeito de compreensão e análise, a comunicação efetiva e os sujeitos e discursos envolvidos (BRAIT; MELO, 2005). As postulações bakhtinianas ancoram a definição do enunciado como a unidade real e concreta da língua, visto que é mediante o enunciado que o discurso se materializa. Assim, cada evento discursivo é único, porque é produzido uma única vez em determinada situação de interação, e dialógico, pois todo enunciado é uma resposta ao que já foi dito e espera uma nova resposta, uma reação ativa por parte do interlocutor.

Nesse processo ativo e dialógico de produção de sentidos entre interlocutores socialmente situados, realizado nas práticas sociais de interação verbal, instaura-se outro caráter fundamental da teoria bakhtiniana, a responsividade. Não cabe mais a visão descontextualizada e a-histórica do interlocutor como mero ouvinte passivo, assim como a compreensão não se constitui simplesmente pelo reconhecimento de sinais. Perseguindo a lógica bakhtiniana, reiteramos que o caráter responsivo, ao mesmo tempo, constitui e está constituído nas interações verbais, mais particularmente, nos enunciados concretos. Enquanto unidades da comunicação verbal, podemos interpretar sua relação com a língua, pelo viés de seu uso social: "Há uma interação orgânica entre a língua e a vida que se dá por intermédio de enunciados concretos” (SOUZA, 1999, p. 94).

Esse caráter responsivo do enunciado concreto reafirma a tese enunciativa de que é preciso que o enunciado, como um todo de sentido, deva instituir um novo elo na cadeia contínua da comunicação discursiva. Essa característica demonstra o caráter dialógico de todo enunciado, já que não existe enunciado fora de uma situação de produção. Ele nasce dialogicamente por meio da apreciação valorativa do locutor, a respeito do tema e do(s) interlocutor(es) de seu discurso, a qual indica as diversas nuances ideológicas refratadas no tratamento atribuído ao tema, refletidas na escolha das formas e do estilo do enunciado. Nas palavras do autor russo: "[...] o enunciado é um elo na cadeia da comunicação discursiva e não pode ser separado dos elos precedentes que o determinam tanto de fora quanto de dentro, gerando nele atitudes responsivas diretas e ressonâncias dialógicas" (BAKHTIN, 2003, p. 300).

Dessa maneira, a escolha dos recursos expressivos no processo de construção de um enunciado concreto se dá no rol de outros enunciados, determinados por suas esferas de comunicação. Nesse processo também existe um movimento dialógico entre os interlocutores, porque ambos requerem recepção/compreensão responsiva ativa dos enunciados. Nessa perspectiva, com o objetivo de se evitar o caos comunicativo, a sociedade se utiliza do que Bakhtin (2003) denominou gêneros discursivos:

[...] O emprego da língua efetua-se em forma de enunciados (orais e escritos) concretos e únicos, proferidos pelos integrantes desse ou 
daquele campo da atividade humana. Esses enunciados refletem as condições específicas e as finalidades de cada referido campo não só por seu conteúdo (temático) e pelo estilo da linguagem, ou seja, pela seleção dos recursos lexicais, fraseológicos e gramaticais das línguas, mas, acima de tudo, por sua construção composicional. Todos esses três elementos - o conteúdo temático, o estilo, a construção composicional - estão indissoluvelmente ligados no todo do enunciado e são igualmente determinados pela especificidade de um determinado campo da comunicação. Evidentemente, cada enunciado particular é individual, mas cada campo de utilização da língua elabora seus tipos relativamente estáveis de enunciado, os quais denominamos gêneros do discurso (BAKHTIN, 2003, p. 261-262, grifo do autor).

$\mathrm{O}$ acento de importância dado à interdependência entre os gêneros e as diferentes esferas da comunicação humana já está marcado na obra Marxismo e filosofia da linguagem. A proposta do Círculo para o estudo da língua segue uma ordem de princípios metodológicos que vai de um macro para um micronível de análise (SOBRAL, 2009). Contudo, esses níveis não deixam de apresentar o vínculo orgânico e dinâmico que preenchem todo o pensamento bakhtiniano. Nesse percurso, em primeiro lugar, encontra-se a tarefa de determinar as condições concretas nas quais as atividades humanas acontecem. Não podemos nos esquecer de que, no olhar dialético do Círculo, as relações sociais evoluem em função das mudanças ocorridas nas infraestruturas. Por isso, evoluem também as formas de interações verbais no interior das inúmeras esferas de atividades humanas, as quais, por seu turno, engendram o funcionamento e o desenvolvimento sociodiscursivo dos gêneros. Enfim, todo esse processo evolutivo reflete-se na mudança das formas da língua.

No caso dos memes, precisamos retomar o conceito de multiletramentos e hipermodernidade para esclarecer como a teoria de gêneros discursivos coaduna com a evolução alcançada pelas tecnologias de comunicação.

Neste sentido, destacamos as ideias de Rojo e Barbosa (2015):

Nunca antes a ideia de que o enunciado é um elo na cadeia verbal, que remete a (e se trama a partir de ou nos) enunciados anteriores e que se estabelece como referência para enunciados ulteriores, a postulação de responsividade ativa no cerne dos atos de compreensão e a concepção bakhtiniana de autoria - como uma orquestração de vozes - puderam ser tão evidenciadas quanto com as novas mentalidades, mídias e ambientes. Para quem se ressentia da ausência de comprovações empíricas mais evidentes e diretas para aceitar as postulações de Bakhtin, eis que os funcionamentos hipermidiáticos e em rede e a prática da remixagem envolvendo diferentes modalidades de linguagem as trazem e encarnam de forma cabal (ROJO; BARBOSA, 2015, p. 120-121).

As autoras explicam que, nas últimas décadas, surgiram novas formas de ser, de se comportar, de discursar, de se relacionar, de se informar, de aprender. Não são as tecnologias que modificam as pessoas, mas as pessoas se modificam, e buscam novas tecnologias que reflitam sua mudança. A internet trouxe a possibilidade de qualquer um ser produtor ou leitor de conteúdo, como afirmam Rojo e Barbosa (2015), possibilitando que todos publiquem na rede e exerçam simultaneamente os dois papéis. 
Se a internet possui muitas vozes, com certeza as que falam mais próximas das pessoas são as redes sociais (Facebook, WhatsApp, Instagram, Twitter, YouTube, Google+, etc.), que são sites em que são possíveis a leitura e a "postagem" de diferentes mensagens discursivas. As redes sociais abriram as portas para a auto-exposição, conforme esclarecem Rojo e Barbosa (2015), nos tempos de hiper (hipermodernidade, hiperconectividade, hiperhedonismo) não basta viver, é preciso contar o que se vive. E podemos discutir as fronteiras entre o público e o privado, o que somos e o que parecemos, o real e o ficcional.

Diante disso, o meme surgiu para dar voz a quem deseja expressar suas opiniões, por isso a quantidade de releituras de uma mesma imagem, fato, vídeo, comentário em rede social. Basicamente qualquer expressão, em rede social, é passível de se transformar em meme. Esse pensamento expande o que imaginamos por discurso, pois na internet ele pode se organizar de tantas maneiras inesperadas, e a originalidade como se apresenta é uma das premissas para que um meme seja viral. Ainda na visão de Silva (2016), a função inicial de um meme na rede virtual pode ser particular, na medida em que diz respeito à intenção de um usuário específico, mas se sua replicação se tornar viral, sua função se torna "socialmente conhecida" (SILVA, 2016, p. 349).

Nesse sentido, o autor justifica o emprego da nomenclatura "textos mêmicos":

Os memes são textos porque atuam como meio de comunicação e transmissão de conhecimento e são mêmicos porque são passados de indivíduo para indivíduo em ambiente virtual por questões de filiação e adesão aos sentidos construídos pelo conteúdo expresso (SILVA, 2016, p. 348).

Portanto, o meme é considerado como um tipo específico de gênero discursivo, na visão de Silva (2016, p. 348), "pelo fato de atender às características prototípicas de um gênero discursivo, inclusive pelo fato de apresentar um projeto de dizer", conteúdo temático, estilo e estrutura.

Silva (2016), ainda em relação ao projeto de dizer de um meme, ressalta a variedade de valores e funções que este gênero pode desempenhar no espaço virtual. Além das intenções humorísticas e satíricas, o meme pode também provocar uma reflexão, problematizar uma situação e, nas palavras do autor: “(...) tudo isso parece ter a ver com o conteúdo temático, com a esfera da atividade a que se relaciona o produtor de um meme" (SILVA, 2016, p. 349), explicação que retoma o conceito de conteúdo temático, que pode ser entendido como o conjunto de conteúdos ideologicamente abarcados através do gênero - o que pode ser dizível numa determinada forma genérica - e nascidos da interação dialógica. Como Rojo e Barbosa (2015) destacam, o gênero meme encontra-se na esfera da vida pública, nas redes sociais, nas perspectivas de produção e consumo. Poderá ter temas políticos, propagandas, temáticas sociais, na maioria das vezes, pelo viés do humor e da sátira, propondo novas formas de mobilização e manifestação de participação social, principalmente para a juventude.

Em relação à estrutura composicional, para a teoria bakhtiniana, a forma composicional de um gênero, apesar de apresentar um aspecto mais fixo, se comparada ao tema e ao estilo, também está vinculada à forma arquitetônica, determinada pelo projeto enunciativo do locutor (SOBRAL, 2009). Nesse sentido, Rodrigues (2008) postula que a diversidade e a heterogeneidade composicional de um gênero são proporcionais à criatividade e complexidade da atividade humana. Acrescenta que a composição estrutural não pode ser associada apenas à organização textual, porque cada gênero vincula-se a uma 
situação social de interação verbal, dada uma esfera social e uma finalidade discursiva. Não podemos deixar de considerar que, dependendo do tipo de relações sociais estabelecidas nas esferas de comunicação discursiva, as formas composicionais dos gêneros podem ser mais ou menos rígidas. Dessa forma, no caso do meme, podemos afirmar que é uma hipermídia de base fotográfica, mas não apenas nela se estrutura, pois também pode apresentar textos verbais, imagens em movimento (gifs) e até vídeos curtos.

Por último, tratamos do estilo. No capítulo intitulado "Os gêneros do discurso", Bakhtin (2003) dedica maior atenção à questão do estilo, justamente por ser de seu interesse avançar na questão dos estudos estilísticos feitos até aquela época. No início desse texto, o autor afirma a existência de uma união orgânica e indissolúvel entre o estilo e o gênero: "Em cada campo existem e são empregados gêneros que correspondem às condições específicas de dado campo; é a esses gêneros que correspondem determinados estilos" (BAKHTIN, 2003, p. 266). Porém, essa relação não se dá em uma única direção, pelo fato de mudanças de estilo poderem alterar a forma composicional de um determinado gênero, evoluindo para outro gênero.

Outro ponto relevante em relação ao estilo é que, conforme Rodrigues (2008), no percurso do dialogismo ao gênero, como outros conceitos do Círculo, ele é uma construção dialógica, social, ideológica. Portanto, o estilo é determinado pelas relações dialógicas estabelecidas entre os interlocutores e, destes, com todos os elementos da situação sócio-enunciativa. $\mathrm{Na}$ construção do estilo entram em cena como fatores determinantes a atitude valorativa do locutor frente ao aspecto temático, aos interlocutores e aos enunciados já-ditos e aos pré-figurados. Sendo assim, embora o meme seja um gênero relativamente novo, seus pressupostos sócio-enunciativos não são. Ele preconiza a ironia, a sátira, a imitação, a amplificação, que não são novidade. Portanto, o estilo do meme será determinado pela relação muito próxima entre ele e as necessidades do nosso momento histórico, quando as pessoas desejam construir uma imagem que as defina, buscando "revelar-se" aos olhos do mundo na tentativa de alimentar seu ethos.

Nesse sentido, corroboramos a ideia de Silva (2016) sobre o meme ser um gênero essencialmente dialógico, porque:

Conserva em si ressonâncias de outros discursos, de outros gêneros oriundos de outras esferas da atividade humana, que o constituem como gênero. Todo meme rememora outros memes (e também outros gêneros), porque com eles dialoga: seja por meio do estilo, da estrutura composicional, do conteúdo temático. [...] ou mesmo pelo fato de ser atravessado constitutivamente por outros discursos, por outras vozes que representam diferentes lugares sociais que se estabilizam e se desestabilizam durante o processo de replicação (SILVA, 2016, p. 352).

De acordo com suas especificidades, esse gênero configura-se como um enunciado muito interessante para as práticas de leitura e análise linguística em sala de aula, pois sua popularidade entre os alunos, sua riqueza sígnica, a variedade de elementos composicionais e a grande quantidade de temáticas são uma vantagem para essas práticas de linguagem. 


\section{O planejamento do protótipo didático: implicações pedagógicas da teoria bakhtiniana com o eixo leitura/análise linguística}

Antes de iniciarmos a seção, faz-se necessário tecermos uma explicação sobre o fato de nos referirmos às práticas de leitura e de análise linguística marcadas pelo uso gráfico de uma barra: a prática de análise linguística, no caso do referido protótipo didático, é vista de forma integrada à prática de leitura, ou seja, priorizou-se a análise linguística no interior da leitura.

Voltando ao momento de planejamento do protótipo, o trabalho foi planejado para uma turma de nono ano do turno vespertino de uma escola da rede estadual do Paraná, situada em uma cidade do interior do estado, que atende, em sua maioria, alunos das regiões periféricas da cidade, pertencentes às classes consideradas socioeconomicamente baixas. Os alunos da turma em questão possuíam um histórico de indisciplina, violência, desmotivação, evasão escolar e reprovações.

Inserida neste contexto, $\mathrm{P}$ planejou e implementou um protótipo didático de $20 \mathrm{~h} / \mathrm{a}$ com o gênero meme. O protótipo foi constituído por quatro eixos temáticos que abordam grandes exemplos de "intolerâncias sociais" (GARCIA; SILVA; FELÍCIO, 2012): bullying, racismo, machismo e homofobia. De acordo com justificativas dadas por $\mathrm{P}$, em relação à pertinência temática dos eixos apontados, essas intolerâncias são experenciadas no ambiente escolar, e, de modo específico, na turma de nono ano em que foi implementado o protótipo. Os problemas de convivência entre os alunos e a falta de respeito nas atividades rotineiras em sala de aula é uma questão preocupante que aflige por demasia os professores, de modo geral. Assim, para compor cada eixo temático P selecionou de cinco a dez memes que remetem aos tipos de intolerâncias sociais escolhidas como temas e outros textos pertencentes a outros gêneros discursivos relacionados aos memes por questões temáticas.

O processo de elaboração didática em questão foi ideologicamente conformado pela pretensão de $\mathrm{P}$ em superar a visão da prática de leitura tradicional, segundo palavras da própria professora: "aquela em que a preocupação maior recai somente para atribuição de nota e a decodificação e reprodução das ideias do texto". A fim, portanto, de tornar a prática de leitura uma ação pedagógica mais significativa para o aluno-leitor, P considerou tanto o aspecto cognitivo quanto discursivo do processo de leitura (LOPES-ROSSI, 2005). Nesta perspectiva, consideramos que o fato de $\mathrm{P}$ observar o processo de leitura também pelo viés cognitivo (MENEGASSI, 2008) lhe deu mais autonomia metodológica para organizar suas aulas de leitura. Desta maneira, os módulos constituem-se em três fases. A primeira fase é a da pré-leitura, que busca acionar o conhecimento prévio do aluno sobre o tema do módulo. A segunda fase, a de compreensão, denominada como leitura-estudo, busca desenvolver o trabalho com os memes por meio de leitura analítica (RODRIGUES, 2008), a fim de se refletir sobre os aspectos enunciativos, e a terceira fase, a pós-leitura, busca desenvolver nos alunos a contra-palavra (GERALDI, 1991). Mais adiante, retomamos teórico-metodologicamente o significado destes conceitos.

Conforme informado na introdução, para este artigo fizemos o recorte de um dos momentos de todo o processo de elaboração didática: o do planejamento de um dos módulos que foram trabalhados com os alunos, o do racismo. Na sequência, relatamos os procedimentos pedagógicos feitos por $\mathrm{P}$ para refletirmos acerca dos aspectos teóricometodológicos de tais ações. 
O módulo buscou desenvolver atividades que evocassem o tema do racismo nos memes selecionados, pois, na visão de P: "podem servir de artifício para validar uma diferença sociocultural histórica entre brancos e negros. Nosso objetivo com esse módulo foi refletir sobre como a língua pode ser instrumento de opressão por meio de memes racistas que disseminam esse pensamento de maneira livre na internet". Diante de tal desejo, no papel de pesquisadora-mediadora/orientadora, não poderíamos deixar de considerar, nesse processo de elaboração didática, o papel de mediador que o professor deve assumir, contemplando as particularidades dos contextos em que atua (HALTÉ, 2008). Assim, P selecionou um vídeo ${ }^{2}$ que trata do racismo no Brasil e suas consequências sociais. A partir deste vídeo, solicitamos que P elaborasse questões orais que pudessem auxiliar a compreensão daquele enunciado pelos alunos. A elaboração da atividade requereu a retomada teórica a respeito da dimensão social do enunciado concreto, no intuito de articulá-la com as especificidades do momento de produção do vídeo. A seguir, apresentamos as atividades.

Quadro 1: atividades da fase 1 do módulo 1.

$1^{\circ}$ ) ATIVIDADES DE CONDIÇÕES DE PRODUÇÃO:

- Onde podemos encontrar esse vídeo?

- Quem produziu o vídeo?

- Por que ele foi produzido?

- Para quem você acha que esse texto foi feito?

$2^{\circ}$ ) ATIVIDADES DE COMPREENSÃO:

- No vídeo, o narrador diz que "a cor da sua pele define a sua vida", explique essa afirmação.

- O texto fala em "representatividade racial". A partir das ideias apresentadas no vídeo, qual o significado dessa expressão?

$3^{\circ}$ ) ATIVIDADES DE INTERPRETAÇÃO:

- Você acha que existe alguém que ainda não sabe o que é racismo?

- Você acha que as informações que o vídeo traz são interessantes?

- Você concorda que a abordagem policial é diferente para brancos e negros?

- Por que você acha que existe racismo?

Podemos constatar que as questões propostas na primeira seção contemplaram alguns parâmetros constitutivos das condições de produção, de acordo com a perspectiva bakhtiniana, a saber: papel social do locutor, papel social do interlocutor, finalidade e espaço de circulação. $\mathrm{Na}$ seção seguinte, as questões trataram de aspectos relativos às ideias principais do vídeo, que exigem um nível inferencial do leitor. Essas atividades poderiam promover maior articulação entre o já-dito e as condições sócio-históricas desse

${ }^{2}$ Vídeo disponível em: <https://www.youtube.com/watch?v=ufbZkexu7E0>. Acesso em: 23 set. 2018. 
dizer para que os alunos entendessem a importância dessas reflexões para o desenvolvimento da sua formação leitora. Mesmo assim, avaliamos que o movimento pedagógico de $\mathrm{P}$, neste contexto, avança positivamente, uma vez que suas atividades possibilitam aos alunos perceberem, mesmo que parcialmente, o vínculo orgânico entre os fatores determinantes da escolha do que o texto-enunciado diz com os objetivos sociodiscursivos e as condições de produção do gênero.

A segunda fase do módulo, cujo objetivo foi o de promover a leitura analítica dos memes selecionados, constituiu-se com os memes e questões a seguir.

Figura 1: meme com cabelo afro.

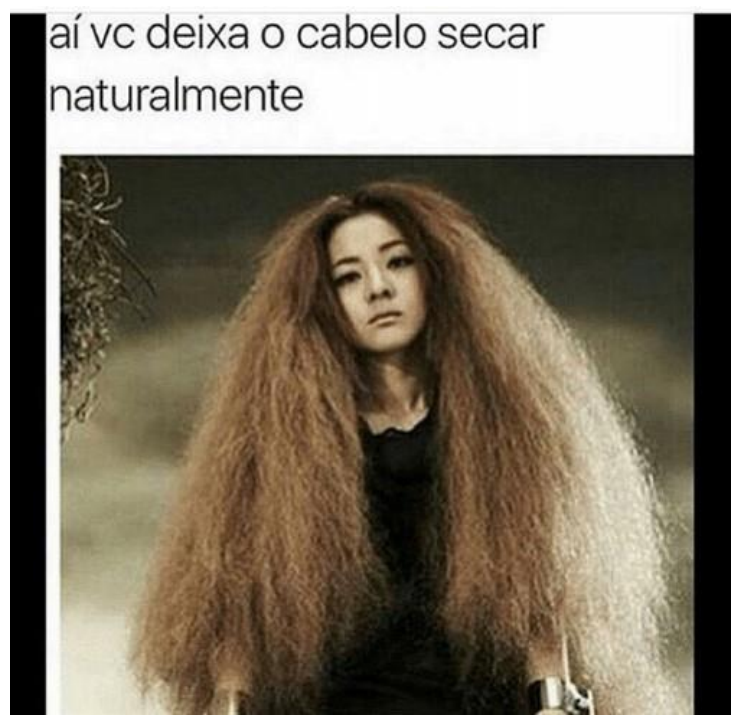

Fonte: <https://pics.me.me/ai-vc-deixa-o-cabelo-secar-naturalmente-essa-foto-representa-21673440.png>. Acesso em: 23 set. 2018.

Quadro 2: atividades da fase 2 do módulo 1.

1) Qual é o texto verbal deste meme?

2) Quem diz esse texto verbal? É a jovem da imagem?

3) Quem é o "você" a que se refere o produtor do meme?

4) Por que o texto verbal foi iniciado com “aî”? Essa expressão é mais comum na escrita ou na oralidade?

5) Qual é a relação do texto verbal com a imagem?

6) Qual a finalidade deste meme?

7) O que a imagem apresenta? De onde ela poderia ter sido capturada?

8) Esse meme pode ser considerado racista? Por quê? 
9) Você considera este meme humorístico? Por quê?

10) Você gostou deste meme? Por quê?

Figura 2: meme "Nego perdeu a noção do perigo".

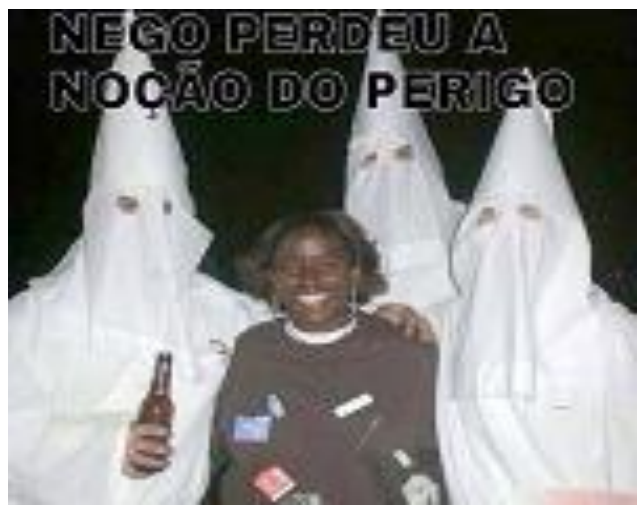

Fonte: <http://correio.rac.com.br/_midias/jpg/2015/04/06/600x390/1_racismo_puc-3531692.jpg>. Acesso em: 23 set. 2018.

Figure 3: meme "Nego não vale nada".

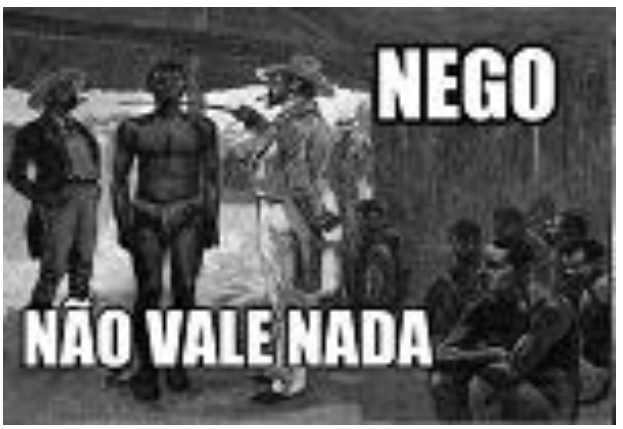

Fonte: <https://versaobetalab.files.wordpress.com/2016/05/1.jpg?w=342\&h=235>. Acesso em: 23 set. 2018.

Figura 4: meme "Nego é retardado".

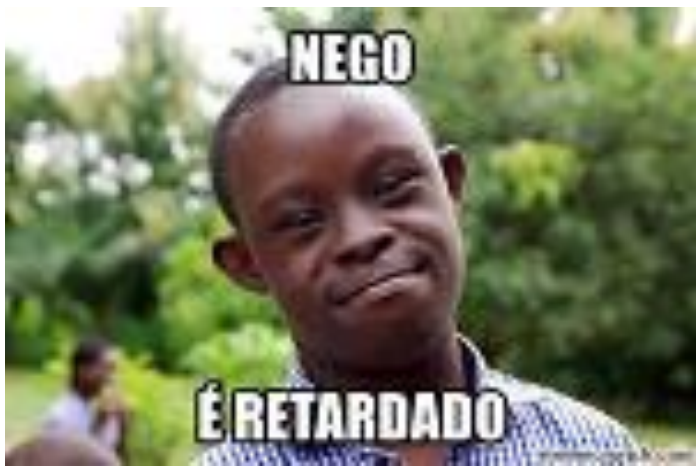

Fonte: <http://www.imagensparawhats.com/wpcontent/uploads/2016/05/13179222_1366093293406662_6472315996830917_n.jpg>. Acesso em: 23 set. 2018. 
Quadro 3: atividades da fase 2 do módulo 1.

Questões sugeridas para a leitura dos memes:

1) Esses três memes apresentam características comuns em relação ao texto verbal. Aponte-as.

2) A expressão "nego" nos memes se refere a quem? Explique.

3) Em relação ao meme 2: o que o fotograma apresenta? Explique.

4) Você conhece um movimento chamado Ku Klux Klan? (Aqui o professor pode mediar uma pesquisa oferecendo material ao aluno).

5) O meme 4 não apresenta uma foto, mas uma gravura antiga. O que ela representa? Explique.

6) O texto verbal dos memes pode ser atribuído a quem? Justifique.

7) Em cada um dos memes, qual a relação do texto verbal com a imagem? Explique.

8) Você considera esses memes racistas? Explique o porquê.

Figura 5: meme "Racista? [...]".

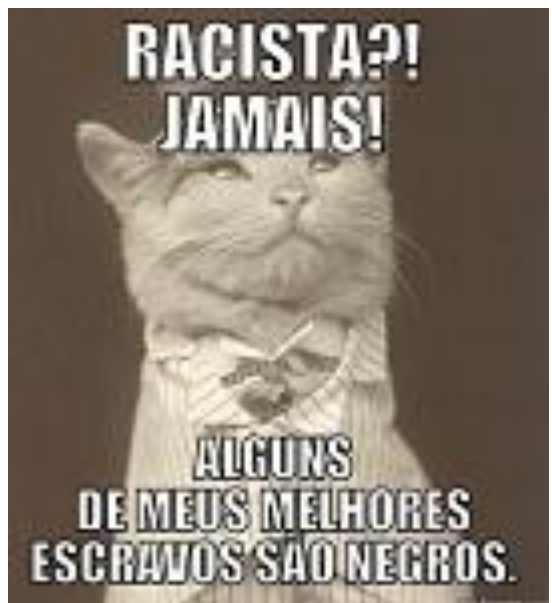

Disponível em: <http://www.quickmeme.com/p/3vzij5/page/2/>. Acesso em 23 set. 2018.

Atividades:

1. Qual o texto verbal desse meme?

2. Qual a função da pontuação utilizada na $1^{\mathrm{a}}$ parte deste texto verbal?

3. Como a ideia ou a informação está sendo trazida neste meme: de forma engraçada? Irônica? 


\section{A quem este texto verbal poderia ser atribuído? Explique. \\ 5. Qual a ideia que fica implícita nele? Explique. \\ 6. Qual a relação do texto verbal e da imagem? Explique. \\ 7. Você já ouviu ou leu frases parecidas? Explique. \\ 8. Esse meme pode ser considerado racista? Por quê?}

$\mathrm{Na}$ sequência dos trabalhos, $\mathrm{P}$ elaborou questões para a exploração dos cinco memes selecionados que contemplaram aspectos referentes ao horizonte temático, à sua circulação, à finalidade, à organização textual, ao uso de recursos linguístico-enunciativos (estilo) articulados aos movimentos dialógicos presentes nos enunciados, relevantes para a produção de sentidos do meme. Observamos que as categorias teórico-metodológicas bakhtinianas de dialogismo e gênero discursivo são mobilizadas, na medida em que os exercícios objetivam despertar no aluno a percepção acerca de todo enunciado ser uma resposta ativa a enunciados anteriores e posteriores, dentro de uma dada esfera comunicativa. Retomando em Bakhtin (2003) a ideia de que toda compreensão é de natureza ativamente responsiva e prenhe de resposta, ressaltamos que ela não equivale ao reconhecimento da forma linguística, mas sim, à "interação dos significados das palavras e seu conteúdo ideológico, não só do ponto de vista enunciativo, mas também do ponto de vista das condições de produção e da interação locutor/receptor" (RECHDAN, 2003, p. 2). Nessa direção, os questionamentos elaborados procuraram considerar que a leitura se constituiu em possíveis diálogos com o texto e, como tal, exige o reconhecimento do outro: "[...] porque lendo a palavra do outro, posso descobrir nela outras formas de pensar que, contrapostas às minhas, poderão me levar à construção de novas formas, e assim sucessivamente" (GERALDI, 1991, p. 171). O resultado do movimento dialógico do leitor em reconhecer o outro na leitura de um texto-enunciado é a contrapalavra, que, nesses termos, funciona como característica da compreensão responsiva ativa.

É nesse processo dialógico, no qual o leitor reconhece no texto-enunciado a palavra do outro e a transforma em uma contrapalavra, que se configura o processo de formação do leitor crítico. Por parte do professor, a construção de um fazer pedagógico orientado à formação de leitores críticos requer tomadas de posicionamentos que devem excluir o autoritarismo e o espontaneísmo, entendendo este último pela necessidade de se superar o improviso que tem marcado historicamente o ensino de leitura em nossas escolas (SILVA, 2008). Para que o aluno-leitor desenvolva competências de leitura, como síntese, análise interpretativa, crítica, cabe ao professor, em sala de aula, "[...] assumir uma atitude de "escuta", orientando aprofundamentos, questionando e estimulando a produção de novas sínteses a partir das interpretações fornecidas pelos estudantes" (SILVA, 2008, p. 23). O desenvolvimento de uma postura crítica diante dos textos não ocorre de modo automático em sala de aula, bastando a execução do ato de ler em si mesmo; ao contrário, deve-se instrumentalizar o aluno-leitor em sua caminhada interpretativa. Nesse sentido, a discussão das ideias veiculadas no texto, a partilha para se desvelar horizontes possíveis para a interlocução, o cruzamento de interpretações em benefício da construção de um pensar coletivo do texto são ações pedagógicas que podem melhorar a qualidade da formação do aluno-leitor. Podemos considerar que esse tipo de abordagem em relação à prática de leitura aproxima-se de um estilo docente "internamente persuasivo" (ROJO, 2008, p. 1772). Para a autora, a escolha por estratégias e procedimentos de sala de aula que visam ao diálogo, no sentido bakhtiniano, pode favorecer a réplica ativa por parte dos alunos. 
Por outro lado, se o professor assume a conduta de que existe a "verdade" que deve ser assimilada e reproduzida pelos alunos, expressão única do texto advinda ou da sua interpretação pessoal ou do material didático, estamos mais próximos do "estilo de autoridade" (ROJO, 2008, p. 1772), exigindo dos alunos uma resposta passiva, de aceitação, de revozeamento. Nesses termos, consideramos que Silva (2008) contribui com a discussão proposta por Rojo (2008) quanto ao estilo docente autoritário, ao afirmar que, em uma prática de leitura autoritária, o sentido cristalizado é meramente copiado, eximindo qualquer possibilidade de tensão, de desejo de se gerar mais sentidos a partir dos múltiplos olhares dos alunos evocados pelos textos. Retomando o pensamento bakhtiniano, essa é a falsa concepção da compreensão, a que de saída exclui qualquer réplica ativa. Esse tipo de compreensão subsidia o estudo da língua "morta", aquela que é desvinculada da sua esfera real, do "fluxo contínuo da comunicação verbal" (BAKHTIN; VOLOCHINOV, 1988, p. 107).

Podemos avaliar que a leitura analítica proposta requer que o professor extrapole a postura tradicional de uma aula de leitura, em que bastava a simples apresentação do texto com as perguntas de interpretação. A prática de leitura proposta concretiza-se por procedimentos pedagógicos de natureza mais dialógicos, ou seja, mais próximos da discussão de ideias, do debate, da troca entre alunos e professores.

Em relação especificamente à prática de análise linguística, consideramos que o encaminhamento que predominou quanto à abordagem de estudo das marcas linguísticoenunciativas foi o reflexivo. Apesar de ainda terem permanecido questões que solicitassem ao aluno a função de certas marcas linguísticas dentro do texto sem articular de forma explícita para o aluno esse uso linguístico com as condições de produção do enunciado (por exemplo, caso da questão número 4, do meme 1; e questão 2, do meme 5), a maioria dos exercícios trilhou pela reflexão indutiva. Destacamos que a prática de análise linguística se concentrou no âmbito epilinguístico, levando os alunos a refletirem sobre a articulação entre o verbal e o não verbal, e, principalmente, sobre o efeito irônico do discurso, por exemplo, o caso do meme 5.

$\mathrm{Na}$ sequência, apresentamos a fase três do módulo, cujo objetivo foi o de propiciar ao aluno a produção digital de memes contra o racismo. $\mathrm{P}$ justificou essa atividade afirmando: "Se analisarmos o contexto discursivo do meme perceberemos que ele é um gênero multimodal que circula em ambiente virtual, e para compreender melhor sua estrutura resolvemos pedir que os alunos produzissem estes textos". Na perspectiva de linguagem adotada para o desenvolvimento deste trabalho, consideramos este momento como mais um momento de produção da contrapalavra do aluno. Como a escola oferecia um bom laboratório de informática e uma boa internet, $\mathrm{P}$ planejou essa produção textual no laboratório, para que eles pudessem compartilhar os memes em suas redes sociais e em seus celulares.

Podemos depreender desse processo de elaboração didática experienciado por $\mathrm{P}$ que a noção de condições de produção não representava para a professora um conhecimento totalmente novo, em virtude de já ser utilizado por outros autores voltados ao ensino de língua materna, como, por exemplo, Geraldi (1991). Parece-nos que o novo, quando tratamos da dimensão social do gênero, foi a própria dimensão axiológica da significação dos enunciados. Nesse sentido, podemos interpretar tal fato como consequência do tipo de formação, tanto inicial quanto continuada, a que $\mathrm{P}$ foi submetida. Essa formação pode ter pecado pela naturalização dos saberes do professor, embotando a produção desses saberes, no âmbito da neutralidade discursiva. Ao tratar das vantagens de 
uma formação docente, na perspectiva de ensino de língua materna voltada para a prática social, Kleiman (2007) analisa exatamente o quanto essa abordagem é tolhida pelo processo de naturalização dos usos da linguagem:

Uma mudança na atuação do professor depende, necessariamente, de mudanças no curso universitário de formação. Uma delas é uma mudança na concepção da escrita e nas atitudes em relação às práticas letradas, que sofrem um processo de naturalização à medida que se avança no processo escolar. As transformações abrangem a dimensão político-ideológica, uma vez que a naturalização da escrita obscurece o fato de os usos da linguagem não serem neutros em referência às relações de poder na sociedade, o que pode contribuir para a desigualdade e a exclusão, quando a aprendizagem da língua escrita se torna mais uma barreira social para os alunos que não participaram de práticas letradas na sua socialização primária, junto à família. O curso de formação deve funcionar, dessa forma, como um espaço para a desnaturalização, para a efetivação de um paulatino processo de desideologização da leitura e da escrita (KLEIMAN, 2007, p. 17).

\section{Considerações finais}

No geral, observamos que as categorias teórico-metodológicas bakhtinianas de dialogismo e gênero discursivo foram contempladas, tendo em vista que as questões elaboradas objetivaram despertar no aluno a percepção acerca de todo enunciado ser uma resposta ativa a enunciados anteriores e posteriores, dentro de uma dada esfera comunicativa. Apesar de reconhecermos as limitações presentes na proposta pedagógica elaborada, não podemos deixar de considerar os avanços alcançados na direção de apropriação conceitual e metodológica. Em primeiro lugar, verificamos que pensar o texto da perspectiva enunciativa da linguagem e dos gêneros discursivos forneceu a $P$ mais clareza quanto à seleção de procedimentos metodológicos para a prática de leitura. Em termos pedagógicos, no planejamento elaborado, o meme figurou ao aluno como um objeto de aprendizagem atrelado às unidades básicas de ensino, no caso, as práticas de leitura/análise linguística. Os parâmetros metodológicos vislumbraram a apreensão do conhecimento conceitual, o desenvolvimento do saber fazer do aluno (conhecimento procedimental de leitura), promovendo-se, assim, a produção de sentidos dos textos também por meio do conhecimento conceitual sobre o gênero - atitude vista como atividade epilinguística (RODRIGUES, 2008).

A análise empreendida permitiu-nos caracterizar algumas ações pedagógicas pertencentes ao momento do planejamento como mais próximas para a adoção de um estilo docente internamente persuasivo (ROJO, 2008). Entre elas, destacamos:

a) a postura de favorecer a manifestação da palavra do outro, no sentido bakhtiniano, ao se preocupar em instaurar a discussão de ideias, o debate compartilhado;

b) a reflexão específica em torno de conteúdos enunciativos constitutivos e constituídos pelo texto-enunciado meme; por exemplo, pensar sobre os papéis sociais assumidos pelos interlocutores na sua produção, enfim, pensar sobre todas as suas condições de produção;

c) a seleção de memes, cujas abordagens temáticas suscitam réplicas ativas diversas; 
d) a instrumentalização dos alunos para a prática de leitura-analítica dos memes, por meio da prática de análise linguística.

No geral, consideramos que a contribuição para o meio acadêmico foi de ampliar a produção de saberes teórico-práticos para as pesquisas sobre os gêneros em sala de aula, especialmente com as práticas de leitura/análise linguística, demonstrando, mais uma vez, a importância de se discutir no trabalho com o professorado o papel social do texto como enunciado e de que maneira a leitura-analítica do gênero pode contribuir para uma adoção pedagógica mais dialógica.

\section{Referências}

BAKHTIN, M. M. Estética da criação verbal. 4 ed. São Paulo: Martins Fontes, 2003.

BAKHTIN, M. M.; VOLOCHINOV, V. N. Marxismo e filosofia da linguagem. 4 ed. São Paulo: Hucitec, 1988.

BARBOSA, J. P. Trabalhando com os gêneros do discurso: uma perspectiva enunciativa para o ensino de língua portuguesa. 2001. Tese (Doutorado em Linguística Aplicada e Ensino de Línguas) - Pontifícia Universidade Católica, São Paulo, 2001.

BRAIT, B.; MELO, R. Enunciado/enunciado concreto/enunciação. In: BRAIT, B. (org.). Bakhtin: conceitos-chave. São Paulo: Contexto, 2005, p. 61-78.

GARCIA, C. B; SILVA, F. D. S.; FELÍCIO, R. P. Projet(o)arte: uma proposta didática. In: ROJO, R.; MOURA, E. (org.) Multiletramentos na escola. São Paulo: Parábola Editorial, 2012, p. 123-146.

GERALDI, J. W. Portos de passagem. São Paulo: Martins Fontes, 1991.

HALTÉ, J. F. O espaço didático e a transposição. Fórum Linguístico, Florianópolis, v. 5, n. 2, p. 117-139, jul.-dez. 2008.

KLEIMAN, A. Letramento e suas implicações para o ensino de língua materna. Revista Signo, Santa Cruz do Sul, v. 32, n. 53, p. 1-25, dez. 2007.

LOPES-ROSSI, M. A. G. Gêneros discursivos no ensino de leitura e produção de textos. In: KARWOSKI, A. M.; GAYDECZKA, B.; BRITO, K. S. (org.). Gêneros textuais: reflexões e ensino. União da Vitória: Kaygangue, 2005, p. 79-94.

MENEGASSI, R. J. Práticas de avaliação de leitura e formação do leitor: reconstruindo conceitos do professor. Leitura, Maceió, n. 42, p. 35-65, jul./dez. 2008.

RECHDAN, M. L. A. Dialogismo ou polifonia? 2003. Disponível em: https://www.ufrgs.br/soft-livre-edu/polifonia/files/2009/11/dialogismo-N1-2003.pdf. Acesso em: 23 set. 2018. 
RODRIGUES, R. H. Pesquisa com os gêneros do discurso na sala de aula: resultados iniciais. Revista Acta Scientarium - Language and Culture, Maringá, v. 30, n. 2, p. 169175, 2008.

ROJO, R. Gêneros de discurso/texto como objeto de ensino de línguas: um retorno ao trivium? In: SIGNORINI, I. (org.). (Re)discutir texto, gênero e discurso. São Paulo: Parábola Editorial, 2008, p. 73-108.

ROJO, R.; BARBOSA, J. P. Hipermodernidade, multiletramentos e gêneros discursivos. São Paulo: Parábola, 2015.

ROJO, R; MOURA, E. (org.) Multiletramentos na escola. São Paulo: Parábola Editorial, 2012.

SILVA, A. A. da. Memes virtuais: gêneros do discurso, dialogismo, polifonia e heterogeneidade enunciativa. Revista Travessias, v. 10, n. 3, p. 341-361, 2016.

SILVA. E. T. Unidades de leitura - trilogia pedagógica. Campinas: Autores Associados, 2008.

SOBRAL, A. Texto, discurso, gênero: alguns elementos teóricos e práticos. Nonada Letras em Revista, v. 1, n. 15, 2010, p. 9-29. Disponível em: https://seer.uniritter.edu.br/index.php?journal $=$ nonada\&page $=$ article\&op $=$ download\&pat h $\% 5 \mathrm{~B} \% 5 \mathrm{D}=264 \&$ path $\% 5 \mathrm{~B} \% 5 \mathrm{D}=177$. Acesso em: 23 set. 2018.

SOUZA, G. T. Introdução à teoria do enunciado concreto do Círculo de Bakhtin/Volochinov/Medvedev. São Paulo: Humanitas, 1999. 